\title{
Macroeconomic Variables and Rising Food Prices: Empirical Evidence from Pakistan
}

\author{
Hamid Salman \\ Institute of Professional Development \\ Islamabad \\ Pakistan \\ Faisal Aftab \\ Department of Research \\ Bahria University, Islamabad \\ Pakistan \\ Rab Nawaz Lodhi \\ Institute of Business and Management \\ University of Engineering \& technology, Lahore \\ Pakistan
}

\begin{abstract}
Purpose: This study examines the long and short-run impact of macroeconomic variable on rising food commodities prices.

Methodology/Sampling: For this paper mixed method approach is used, quantitative time series data over the period 1991-2013 and autoregressive distributed lag (ARDL) approach to Co-integration, whereas qualitative data is collected from thematic analysis of many past researches in order to determine the most and least critical consequences of food prices skies by using NVIVO 10 software technique "tree map".

Findings: The result shows energy prices and dollar prices have positive beta coefficients and having statistically significant impact on rising food commodities price index Moreover, the error correction model's coefficient is with negative sign that suggests its expected significant adjustment toward long-term. Whereas the qualitative results identified different variables have different magnitude of relationship with rising food prices in different situation; Exchange rate, energy prices, money supply are the most critical consequences of rising food items prices.

Practical Implications: The study therefore recommends that government should develop and integrated efficient and effective energy and monetary policy with long-term future development outline of controlling food inflation.
\end{abstract}

Keywords: Food Prices, Critical consequences, Developing country, ARDL, NVivo.

JEL Classification: E6, Q18.

\footnotetext{
*The material presented by the authors does not necessarily portray the viewpoint of the editors and the management of the Institute of Business \& Technology (IBT).

* Hamid Salman: hamidsalman@gmail.com

* Faisal Aftab: faftad@bahria.edu.pk

* Rab Nawaz Lodhi:

CJMSS is published by the Institute of Business and Technology (IBT). Main Ibrahim Hydri Road, Korangi Creek, Karachi-75190, Pakistan.
} 


\section{INTRODUCTION}

Inflation is basically the untiring increase in the prices of commodities and services in a country with time or decreasing the value of money, in other words, it can be defined as continues reduction in purchasing power of the consumers. Just like Milton Friedman has defined inflation in term of income distribution as inflation is inclines to relocate the income and capital by taking it away from salary earning poor people who are supposed to use it towards much profit earning peoples of the community who are connected with both to save money and to invest their savings (Friedman, 1963).

Inflation is the most important global macroeconomic issue because of its argumentative effects on economy as it interrupts the balance of economic society by raising the prices of goods and services or by reducing the value of the currency in a country. In such condition, no local and foreign investors come with their investment, therefore the flow of local and foreign direct investment goes downward, which leads to upward movement in unemployment rate, normal daily life expenditure also increases along with decrease in savings; all these negatively affect the GDP per capita and GDP growth rate of the nation. Economist said that inflation occur in two ways; one, when prices of resource inputs increases which escalate the cost of production upward and in return producers raises the prices to keep their profit at a suitable or demanded level, which known as cost-push inflation, while, the second, when worker required higher wages due to increased labour cost then again in turn producers raises the prices to cover up their such cost and maintain profit margins is known as demand-pull inflation.

In developing countries like Pakistan food price inflation is also one of the major crucial problems because of its aggregate adverse pressure on national economy and purchasing power or real income of the consumer (Shahzad and Joiya, 2013) and it put sever negative effect on poor people because they spend major portion of their budget income on consumption of food (IMF, 2011) that's why, the food inflation is a key factor and the focal point of attention for economist and policy makers respectively to maintain it at adequate level. Although Pakistan have steady downward movement of inflation rate after the world financial crisis of 2008, but food prices continually rises which put negative pressure and burden on poor people lives notably on their budget share of non-food items like education, transportation and health; currently Pakistan has an inflation rate $8.53 \%$ as shown in the Figure.1, which, is still on higher side as it is above the 6 percent limit according to Sherani and Sakib (2005) in developing country like Pakistan to see the significant positive effect on economy an acceptable rate of inflation have always around 3 to 6 percent (Khan, 2005 and Hussain, 2005). Figure 1 also showing the upward movement of consumer food prices index. 
Figure 1

Pakistan Inflation Rate and Consumer Price Index (CPI) Trend
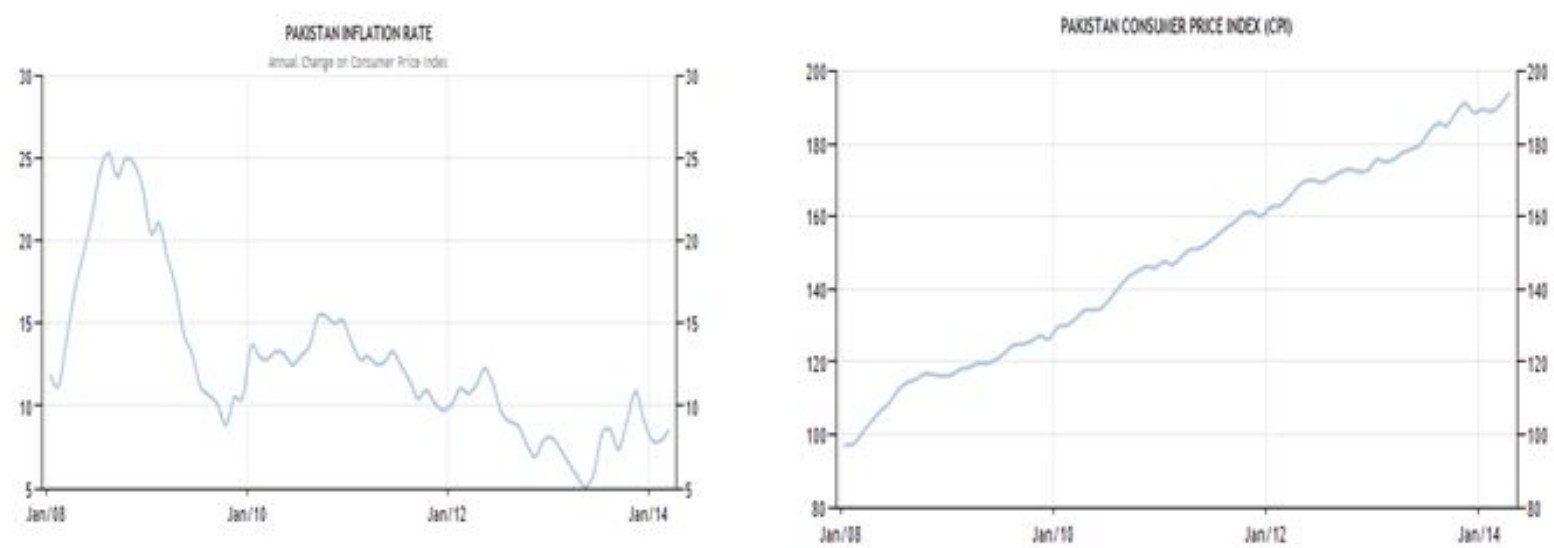

Source: $\underline{w w w . t r a d i n g e c o n o m i c s . c o m}$

United Nations Inter Agency Assessment Mission (2008), reported that the households of poor community in Pakistan have spends seventy percent of their budget on food item's consumption, thus hardly meet their essential need of education and health they often comprise on it; in response they have more ratio of school dropout in the country, leading to more difficult and hard for country to achieve its Millennium Development Objectives of 100 percent primary schooling and removal of starvation.

Various studies have been conducted previously by different researcher on determinants of food inflation in Pakistan like Mushtaq et al. (2011), Khan and Qasim (1996), Kemal et al. (2012), Asjed et al. (2013) Tan et al. (2002), Khan et al. (2007), Jalil et al. (2013), Khan \& Saqib (2010), Shahzad and Joiya (2013), Batten et al. (2013), Arinze E Peter (2011) some of them focused on internal fiscal or monetary policy factors causes inflation and some of them considered external factors causes inflation more but very little and no appropriate research have been conducted to examine the causes of inflation by incorporating both internal and external factors. The general rise in food-prices in the developing country like Pakistan is for the reason of higher monetary development affected by great amount of borrowing from public and Private sector in order to cover up fiscal deficit (Khan and Qasim, 1996) but the monetary and fiscal policy are not the only independent factors caused inflation there are also some external factors i.e. international commodities prices have effect on inflation in developing countries. Therefore in present study the attempt has been made to determine the influence of internal and external factors namely, Energy Prices (EP), Dollar Prices (DP) and household final consumption (HFC) respectively on rising food prices in Pakistan.

This Study will provide help to the economists, policy makers and the experts attached with industrial and manufactured sector to analyze the elements that mostly altered the food items prices in developing countries e.g. Pakistan.

To study the casual relationship between Energy Prices, Dollar Prices and householdfinal consumption and rising food prices in Pakistan. 
$>$ To identify the major consequences of rising food commodities prices in Pakistan

$>$ To provide the recommendations to Government and Economic policy makers.

Using the secondary source of time series annually basis data from 1991 to 2013, Autoregressive Distributed Lag (ARDL) to Co-integration technique has been applied to analyze the long-term and short-term cause and effect relationship between Energy Prices (EP), Dollar Prices (DP), household final consumption (HFC) and Rising Food Prices (FP) in the context of Pakistan, similarly Qualitative thematic analysis of various previous researches has been used to extract the major and least critical consequences of rising food commodities prices by applied different test in NVIVO 10. Paper further divided as literature review, methodology, Data analysis and conclusion with policy recommendations.

\section{LITERATURE REVIEW}

From many previous researches; one study related to food prices in Pakistan was conducted by Khan \& Qasim (1996) showed that determinants of CPI food and non-food inflation are different; having divergent trends in economy by using data of time series from 1971-72 to 1994-95 and applied Johensen Co-integration to Error correction model on separate equations. Results concluded that CPI food inflation is co-integrated and having long-run relationship with supply of money, value added agricultural products, supported wheat prices whereas money supply is significantly associated with food inflation. Mushtaq et al. (2011) determine the relationship of monetary macroeconomic indicators with wheat price index in Pakistan by applied Johansen's co-integration model; they found long-run significant relationship between real supply of money, real wheat prices, trade openness, and real exchange rate. Kemal et al. (2012) conducted a study in Pakistan to examine the determinants of food inflation by considering the supply and demand side factor in the model (food prices, per capita income, Money supply, agricultural sector subsidies, output of food items per year and energy prices); used time series data from 1970- 2010 and apply autoregressive distributed lag model; they concluded agricultural sector subsidies have minor impact on downfall of food item prices for long-run, because of little or no import ; the world food prices put their pressure on domestic markets to raise the country own manufactured food items prices therefore it create imported inflation. They also concluded that only Money supply is the only significant variable which causes food commodities prices significantly in short and long-run simultaneously.

Asjed et al. (2013) conducted a study in the context of Pakistan to investigate and measure the impact of domestic and non- domestic factors of economy (output gap, growth in reserve money, expected future inflation, foreign inflation, 2008 financial crises) on Inflation in long-run and short-run; they have used ARDL approach with time series data of selected variables from period 1972 to 2010 and resulted that only money supply has long -run significant positive impact on inflation whereas all other variables have short-run significant positive effect on inflation, therefore policy maker should seriously considered global crisis in order to develop policy regarding maintaining inflation. Tan et al. (2002) conducted a research in Malaysian economy to determine the impact of important internal and external economic factors on Malaysian inflation and also to examine the to inspect the presence of international and intra-ASEAN inflation diffusion to Malaysian inflation; they have used quarterly basis time series data of eleven internal and external economic variables (internal consumer price index, exchange rate, capital inflow, money supply, Gross domestic product/income, interest rate, private consumption, trade balance, government expenditure, world inflation and rest of ASEAN's inflation) from the period 1973:1 to 1997:2 and applied 
multivariate co-integration to error correction model along with impulse response functions and variance decomposition techniques. Results shows that external economic variables have significant impact on Malaysian inflation rather than internal economic factors due to open trade Malaysian economy, especially rest of ASEAN, inflation and exchange rate have direct relation with Malaysian domestic inflation, money supply and government expenditure have indirect relation through exchange rate, interest rate have relation through government expenditure, private consumption have indirect relation through interest rate. Whereas Income, trade balance, capital inflow and world inflation have neither direct nor indirect association with internal inflation.

Khan et al. (2007) attempt to identify the major demand side and supply side determinants of inflation in Pakistan by using the time series annual basis data from 19972 to 2006 and applied Ordinary least square (OLS) method; they found all subjected variables (real demand, inflation expectations, import prices, exchange rate and private sector credit) have positive significant effect on food price inflation, whereas contribution of fiscal policy variables to ward food inflation was calculated minimum or minor. Jalil et al. (2013) conducted a research in Pakistan to determine the fiscal policy determinants of inflation and also to examine significant long-run impact of fiscal policy factors on inflation. The variables incorporated here were Government sector borrowing, private sector borrowing, central government deficit, aggregate demand aggregate supply, trade openness, lending rate, oil prices, import prices, and wheat procurement prices; they have used time series annual basis data from 1972 to 2012 and applied autoregressive distributed lag model which conclude the dominance of fiscal policy over inflation as all variables have significant positive impact on inflation.

Durevall (2012) conduct a study in Ethiopia and Kenya for time period 2000 to 2011 to analyze the determinants of the inflation through the channel of consumer price index (CPI) in both the selected countries by using economic variables exchange rates ,additional money supply, domestic agricultural supply shocks, world energy prices, world food items prices and world non-food items prices, used Co-integration to error correction model to examine the long and short-run relationship, they found in both studied countries inflation rate are controlled by same determinants like world food prices and exchange rate showing positive significant long-run impact on inflation rate whereas money supply and agricultural supply shocks have short to medium-run significant positive impact on inflation rate. Shaari et al. (2012) study the influence of oil prices changes and exchange rate on inflation in Malaysian economy by using Vector error correction approach to determine the short and long-term effect on inflation. Monthly data of crude oil price index, consumer price index (CPI) and exchange rate were used for the period of 2005 to 2011. The result of all test applied on the model shows that variables were stationery at 1 st difference and there is significant long run association among all variables presented in model. Whereas in short-run only changes in crude oil price have significant effect on inflation whereas exchange rate has no significant influence on inflation. Malaysian state government should adopt right policies to have control on oil prices to resist rate of inflation.

Due to the rapid and continuously rise in the oil product prices during the time period from 1990 to 2010 causes instance pressure on economy, Arinze E Peter (2011) conducted a study in Nigerian economy to examine the effect of oil price volatility on inflation in term of cost of living and income distribution within the country by using the simple regression analysis he found the significant positive relationship between oil price hike and inflation rate by discovering the higher oil prices causes high inflation which lead to high cost 
of living and unequal income distribution therefore government need to explore the new energy resources to broaden up the horizons of energy supply. Trung \& Vinh (2011) conducted a study in Vietnam economy to examine the impact of oil prices changes, real effective exchange rate and inflation rate on GDP output of the country by using vector autoregressive (VAR) modeling and Co-integration with monthly basis time series data from 1995 to 2009 and found that oil prices and depreciating exchange rate have significant positive impact on GDP output but depreciating exchange rate have strong significant positive impact on economic activity compared to oil price changes. Inflation has less significant positive impact on GDP in Vietnam. Salim \& Rafiq (2011) performed a research to study the effect of oil price instability among six emerging Asian economies China, India, Indonesia, Malaysia, Philippines and Thailand by using monthly basis secondary data from 1999:2 to 2009:1 and VAR analysis along with the Granger causality test to assess the short and long-run effects. The results show that oil price instability associated positively with economic Growth and negatively associated with inflation in most of the six studied emerging Asian economies. While VAR analysis along with the Granger causality test interpret that GDP and inflation both effect oil price instability significantly in India, Indonesia \& Malaysia whereas only GDP effect oil price stability significantly in China, Philippines and Thailand. Government has to keep following its policy of subsidization to soothe the domestic oil price in order to bring stability in economic growth.

Soderblom \& Alem (2010) conducted a research in Ethiopia to determine the impact of food price inflation and idiosyncratic shocks on Household consumption level in urban areas by using mixed method research whereas the qualitative data shows that upward going food price inflation adversely effect in greater magnitude specially during the period of economic shock between 2004 to 2008 similarly the quantitative results through regression analysis shows that low assets households and poor workers were negatively hit by higher food prices. Special efficient low assets household targeted governmental aid programs should be applied in response to food prices shocks. Sekhampu \& Dubihlela (2012) perform a research in Bophelong (South Africa) to study the perception of low income urban household in order to determine the impact of rising food prices. Quantitative research method was applied and data from household were collected through survey questionnaire; 300 selfadministrative questionnaires were distributed among the households of in Bophelong (South Africa) and logistic regression technique used. Results indicates that majority of low income adversely effected from rising food prices but the magnitude of rising inflation depend on various socio-economic and demographic factor of households. Rayes (2010) stated in World Bank report that strategies of poor household on consumption pattern were different from non-poor households. As when prices of food commodities goes up; poor household cut their quantity of food item consumption and shifted on the use of cheaper food items whereas the non-poor household reduce the consumption of non-food items but not food item consumption.

\section{THEORETICAL FRAMEWORK}

Theoretical framework is developed and clarified the logical linkage and relationship among the selected variables of the interested research study. The theoretical framework shows the integral part of variables and discusses dynamic situations which being investigated studied in the study through the interrelationship among the variable. Such conceptual framework helps researcher to develop necessary postulate or hypothesis in order to test certain relationship and to expand our knowledge of the situational dynamic. In short theoretical 
framework demonstrates how the selected variables associate with each other (Sekaran U, 2006).

There are different theories of inflation but here only two of them are discussed "demand pull inflation" and "cost push inflation" as these two are most related to the interest of present study. Demand pull inflation occur when consumption of particular product increases, demand also increases but if the supply of the particular product lacking so at this stage demand and supply disequilibrium occur and due to the shortage of those goods people want to purchase at any price level and in result increase prices lead to inflation, in this study household final consumption affect the food inflation under demand pull inflation theory.

Cost push inflation occur when increase in cost of production will also increases the prices of particular product and services to maintain the corporate profits. In this study "energy prices and dollar prices directly affect food inflation rate because devaluation makes our currency cheap compare to other currencies and make all goods cheap due to which prices in term of rupees and make expensive all those good which prices are in term of dollar, thus due to purchase of imported raw material, goods and services prices will increases and lead to inflation. In this study we used research model to analyze the impact of Energy Prices (EP), Dollar prices (DP) and household final consumption (HFC) on food price index, research model's conceptual frame work and given below.

Figure 2

Conceptual Model

\section{Independent variables \\ Dependent variable}

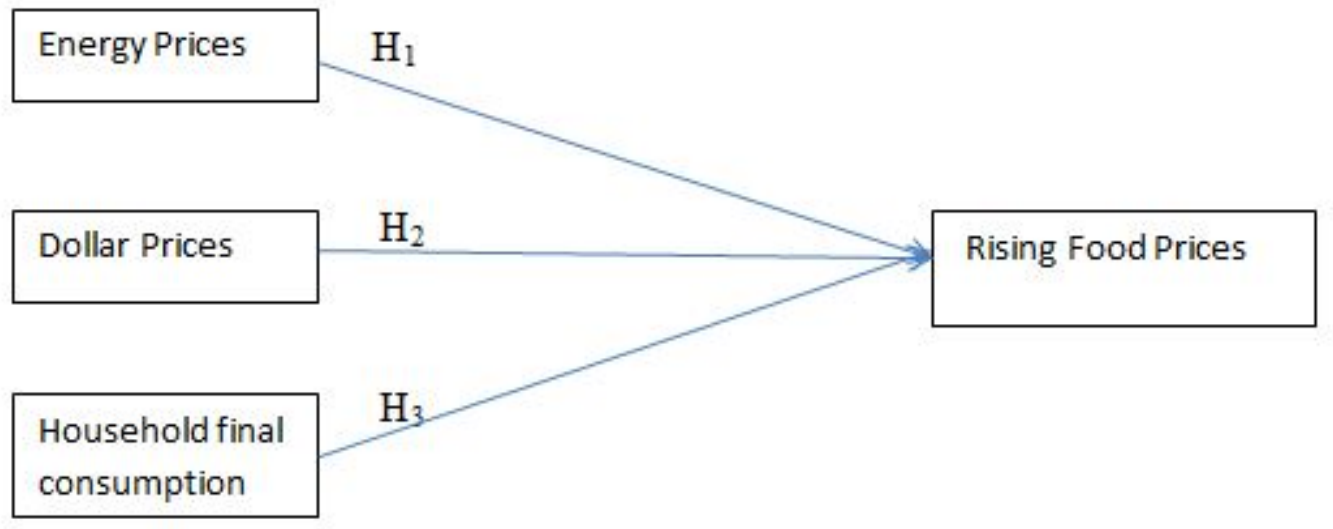

In the figure 2 the independent variables are taken as Energy prices(average crude oil, natural gas, coal and hydro prices), Dollar prices (exchange rate Rupee per dollar) and Household final consumption expenditure ( $\%$ of annual GDP) while the Food prices (Consumer price index of food items) taken as independent variable.

\subsection{Relationship between Energy prices and Rising Food Commodities Prices}

Crude oil prices have significant influence on rising food prices, many past studies have revealed that crude oil prices have positive influence on rising food price 
inflation in some context and also negative influence of oil prices on food price inflation have been discovered in some context like Arinze E Peter (2011), Davidson et al. (2011) and Shaari et al. (2012) conducted research on inflation in Nigeria, United kingdom, Malaysia respectively and found significant positive relationship between inflation and crude oil prices Salim \& Rafiq (2011) conducted in Vietnam, Pakistan and six emerging Asian countries China, Thailand, Malaysia, India, Indonesia and Philippines. On the basis of above mentioned past studies, the following hypothesis will be examined.

$\mathrm{H}_{\mathrm{A} 1}$ : Energy prices have significant positive effect on food price index

\subsection{Relationship between Dollar prices and Rising Food Commodities Prices}

Different past studies like Mushtaq et al. (2011), Tan et al. (2002), Khan et al. (2007), Durevall (2012), in their monetary model of inflation found that exchange rate (dollar price) have positive significant effect on food price inflation and core inflation. On the other hand Shaari et al. (2012) conducted research on inflation determinants in Malaysia incorporated both demand side and supply side factors in model and found that exchange rate has negative impact on core inflation. Based on these above mentioned past studies, the following hypothesis will be examined.

$\mathrm{H}_{\mathrm{A} 2}$ : Exchange rate (Dollar prices) has significant positive effect on food prices.

\subsection{Relationship between Household Final Consumption Expenditure and Rising}

\section{Food Commodities Prices}

Many past studies like Tan et al. (2002), Soderblom (2010), and Dubihlela (2012) conducted separate researches on different context to analyze the impact of higher food prices on household consumption and found that rising food prices have direct and significant but adverse or negative relationship with household consumption. Based on these above mentioned past studies, the following hypothesis will be examined.

$\mathrm{H}_{\mathrm{A} 3}$ : Household final consumption has significant negative effect on food prices

\section{RESEARCH METHODOLOGY}

The study is an explanatory sequential and mixed method research in nature because the objective of the current study is to determine the impact of macro-economic variables on rising food prices in Pakistan and also to identify different thematic results of rising food prices and their linkage with productivity of people belong to different income class in Pakistan. In this study two distinct approaches have been applied for collection of data; Quantitative time series annually basis data has been collected from 1991 to 2013 for selected variables of the research like Energy Prices (EP), Dollar Prices (DP) and household final consumption (HFC) and Food commodities price index from the authentic sources like World Bank Economic Development Indicator (WDI). For Qualitative analysis 22 most relevant past researches has been used from different research papers databanks e.g. Google Scholars, 
Science direct etc. The selection of the data sample was directed the availability consideration; also followed by principal limit theorem

First selected time series data will be inspected to check out the stationarity level by using the most widely used statistical techniques like Augmented Dickey-Fuller test (1979) and then applied Autoregressive Distributed Lag (ARDL) model to determine the equilibrium based long run association between energy prices, dollar prices, household final consumption and rising food price index in Pakistan whereas ARDL approach is quite new and advanced econometric technique from Johensen Co-integration and Granger Casualty test; which has several advantages (Lodhi, Malik, \& Habiba, 2013) i.e. Firstly, ARDL test can applied whether the variables are stationery at I (0), I (1) or at combination of both. Secondly the ARDL has maximum twelve lags to capture and produce data from universal to specific modeling framework. Thirdly the error correction model (ECM) derived from ARDL after through a simple alteration; which combine the equilibrium based short-term and long-run relationship without losing long-term records settings. Fourthly ARDL approach has a unique quality which set it apart from Jusilius Johensen Co-integration tests that it can produce results with small sample size. Fifthly ARDL approach is restricted from the correlation of residual. Pesaran \& Shin (1999) defined that ARDL econometric technique adjust the endogeneity and serial correlation problematic issues

$$
\mathrm{FP}_{\mathrm{t}}=\mathrm{f}(\mathrm{EP}, \mathrm{DP}, \mathrm{HFC})
$$

Where FP is food commodities price index, EP is Energy prices (included Crude Oil, Coal and natural gas combine price index), DP is Dollar price/exchange rate (Dollar per Rupee) and HFC is Household final consumption percentage of GDP.

$$
\mathrm{FP}_{\mathrm{t}}=\beta_{0}+\beta_{1} \mathrm{LnEP}_{\mathrm{t}}+\beta_{2} \mathrm{LnDP}_{\mathrm{t}}+\beta_{3} \mathrm{LnHFC}_{\mathrm{t}}+\mathrm{e}_{\mathrm{t}}
$$

$\begin{array}{ll}\mathrm{FP}=\text { food price index } \quad \beta_{0}=\text { constant } & \beta_{1}=\text { change in Energy prices } \\ \mathrm{LnEP}_{\mathrm{t}}=\text { logarithms of Energy prices, } & \beta_{2}=\text { change in Dollar Prices } \\ \mathrm{LnDPt}=\text { logarithms of Dollar prices/Exchange rate } & \beta_{3}=\text { change in Household Final } \\ \text { ConsumptionLnHFC }=\text { logarithms of Household Final Consumption } & \\ \mathrm{e}_{\mathrm{t}}=\text { Noise error term } & \end{array}$

ARDL test has been applied for null hypothesis acceptance or rejection on the basis of F-test which regardless of stationary level has a non-standard distribution at $\mathrm{I}(0)$ or I(1).

$\mathrm{H}_{0}=$ There is no co-integration between variables $\left(\mathrm{C}_{\mathrm{n}}=0\right)$

$\mathrm{H}_{1}=$ There is co-integration between variables $\left(\mathrm{C}_{\mathrm{n}} \neq 0\right)$

Pesaran et al (2001) determined two lower and upper bounded critical values. The lower level critical value undertake the stationarity of series at $1(0)$ and upper level critical value undertake the stationarity of series at 1(1). So if the computed value of F-statistic is greater than upper level limit critical value then rejects $\mathrm{H} 0$ means there is Co-integration but 
if F-statistic computed value is smaller than upper level critical value then rejects $\mathrm{H} 1$ means there is no Co-integration.

\section{RESEARCH FINDINGS}

\subsection{Empirical Findings}

Table 1

Augmented Dickey-Fuller Test Results for Unit Roots

\begin{tabular}{lcccccc}
\hline $\begin{array}{l}\text { Variables } \\
\text { @ level }\end{array}$ & $\begin{array}{c}\text { ADF } \\
\text { Statistic }\end{array}$ & Prob. & $\begin{array}{c}\text { Variables } \\
\text { at 1 } \\
\text { Difference }\end{array}$ & $\begin{array}{c}\text { ADF } \\
\text { Statistic2 }\end{array}$ & $\begin{array}{c}\text { Prob. } \\
\text { Stationarity } \\
\text { remarks }\end{array}$ \\
\hline Ln_FP & 0.017823 & 0.9507 & DLn_FP & -3.857039 & 0.0086 & I(1) at 1\% \\
Ln_EP & -0.145724 & 0.9322 & DLn_EP & -4.50736 & 0.0022 & $(1)$ at $1 \%$ \\
Ln_DP & -1.494195 & 0.5177 & DLn_DP & -4.190724 & 0.0042 & I(1) at 1\% \\
Ln_HFC & -4.334800 & 0.0028 & & & I(0) at 1\% \\
\hline
\end{tabular}

Where:

Ln_FP is natural logarithm form of food prices (Dependent Variable)

Ln_EP is a natural logarithm form of energy prices

LN_DP is a natural logarithm form of dollar prices

LN_HFC is natural logarithm form of household final consumption expenditure (Independent Variable)

To start process of results estimation, first step is to check the stationarity of each series of variable used in research model, therefore Augmented dickey fuller test is applied here; ADF test is widely used to established the linearity, stationarity and order of integration for each individual variable time series. (Trung \& Vinh, 2011) In this regard the Table 1 showing the output of unit root test on each variable time series at level and first difference.

Overall summary of the ADF test results shows that only "Household final consumption" is stationery at level; p-value is less than $5 \%$ at level whereas all the other selected variables (Food price index, energy prices and dollar prices) are stationery at $1^{\text {st }}$ difference because the Probability value of each variable is less than $5 \%$ at $1^{\text {st }}$ difference. So all variables are stationery at level and first difference and no variable is stationery at $2^{\text {nd }}$ difference which fulfills the assumption of ARDL Test which says no variable should be stationery at $2^{\text {nd }}$ difference (Lodhi, Malik, \& Habiba, 2013).

The current study has the objective to determine the influence of macroeconomics variables on rising food prices and also to determine the significant longterm and short-term relationship among macroeconomic variables and rising food prices; which is interpreted through the descriptive statistics and Autoregressive Distributed Lag (ARDL) tests.

ARDL test has been applied for null hypothesis acceptance or rejection on the basis of F-test which regardless of stationary level has a non-standard distribution at I(0) or I(1).

$\mathrm{H}_{0}=$ There is no co-integration between variables $\left(\mathrm{C}_{\mathrm{n}}=0\right)$

$\mathrm{H}_{1}=$ There is co-integration between variables $\left(\mathrm{C}_{\mathrm{n}} \neq 0\right)$ 
Table 2

Bounds F-test for Co-integration

\begin{tabular}{lccc}
\hline \multicolumn{1}{c|}{ Dependent variable } & Independent variables & Computed F-Statistics \\
\hline FP (Food Price index) & $\begin{array}{c}\text { Energy prices (EP), } \\
\text { Dollar prices (DP) and } \\
\text { household final } \\
\text { consumption (HFC) }\end{array}$ & $\mathbf{4 . 1 6 9 7 7 1}$ \\
Asymptotic & $\mathbf{1 0 \%}$ & $5 \%$ & $\mathbf{1 \%}$ \\
Criticlal value & $\mathbf{2 . 2 0}$ & $\mathbf{2 . 5 6}$ & $\mathbf{3 . 2 9}$ \\
Lower bound & $\mathbf{3 . 0 9}$ & $\mathbf{3 . 4 9}$ & $\mathbf{4 . 3 7}$ \\
Upper bound & & \\
\hline
\end{tabular}

After determining the stationarity of the each selected variables; bounded F-test applied to explore the long-term association between macroeconomic indicators (energy prices, dollar prices and house hold final consumption) and food commodities prices. The Bounded F- Test results in the above Table 2 shows that indicated that Co-integration is present among the model because the F-statistic software computed value which is 4.169771 greater than the upper limit critical value at $10 \%$, and $5 \%$ which mean study rejected $\mathrm{H}_{0}=$ There is no co-integration between variables in favor of $\mathrm{H}_{1}$.

The study used CUSUM and CUSUMSQ to determine the steadiness of the model between upper and lower bound critical value lines.

Figure 3

Plot of Cumulative Sum of Recursive Residuals

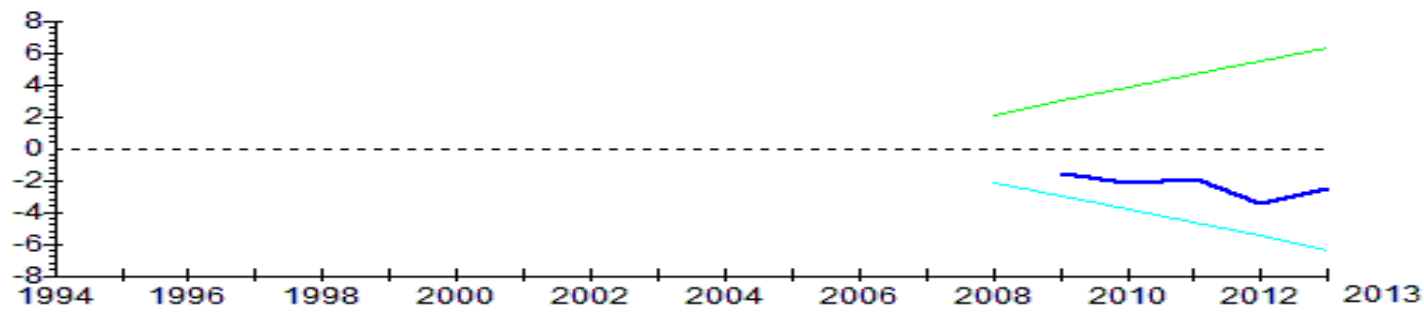

(The straight line represents critical bounds at 5\% significance level)

Figure 4

Plot of Cumulative Sum of Squares of Recursive Residuals

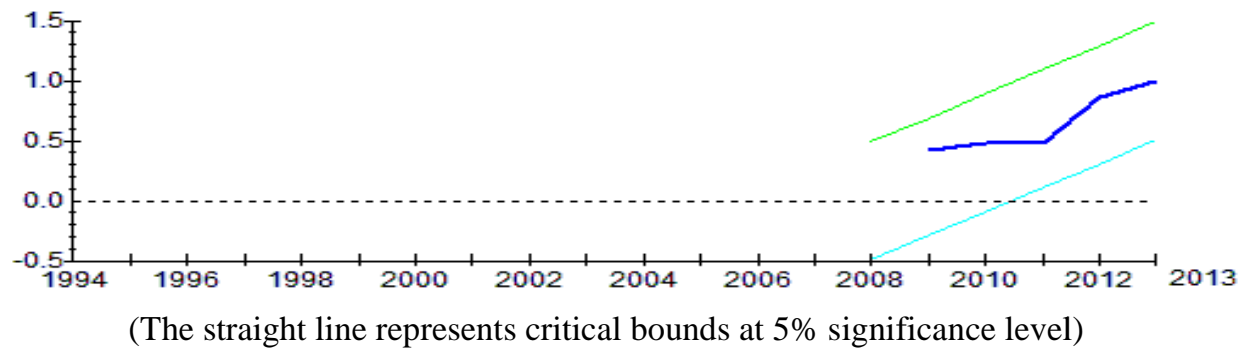

The above mention Figure 4 and Figure 5 of CUSUMSQ shows a reliable pattern between the upper and lower bounded levels which demonstrate that economic model has a significant long run relation. 
After accepting the F-test Alternative hypothesis which mean there exist Cointegration among selected variables; long and short-run coefficient are computed by using related ARDL test after set the maximum length of lag to 4 by chooses Akaike information criteria for final description of ARDL estimates $(3,3,1,3)$ in order to determine the long-run relationships.

\section{Table 3}

Results of Estimated Long-run Coefficnets Using ARDL Approach ARDL (3, 3, 1, 3) Selected Based on Akaike Information Criteria

\begin{tabular}{|c|c|c|c|c|}
\hline Regressor & Coefficient & $\begin{array}{l}\text { Standard } \\
\text { Error }\end{array}$ & T-Ratio & [Prob] \\
\hline$\overline{\text { LNEP }}$ & .47169 & .043219 & 10.9139 & {$[.000]$} \\
\hline LNDP & 2.8471 & .66901 & 4.2557 & {$[.005]$} \\
\hline LNHFC & -.078338 & .054123 & -1.4474 & [. 198$]$ \\
\hline C & -10.5216 & 3.1884 & -3.2999 & [.016] \\
\hline
\end{tabular}

The Table 3 shows the long-run relationship among Food price index, Energy prices, Dollar prices and Household final consumption in Pakistan which expectedly positive. The long run impact of energy prices and Dollar prices on rising food prices index are significantly positive as Probability values are 0.000 and 0.005 respectively which is less than $5 \%$. Coefficient value of energy prices are 0.47169 which mean one unit change energy prices will increase food prices by 0.47169 units similarly co-efficient of dollar prices are 2.8471 which mean one unit change in dollar prices will increase food prices by 2.8471 units. Whereas long-run impact of household's consumption on food prices is negative but insignificant as co-efficient value is -0.078338 and $\mathrm{P}$-value is 0.198 which is greater than $5 \%$.

Table 4

Error Correction Representation for the Selected ARDL Model ARDL (3, 3, 1, 3) Selected Based on Akaike Information Criteria

\begin{tabular}{lllll}
\hline Regressor & Coefficient & Standard Error & T-Ratio & Prob \\
\hline dLNFP1 & .27028 & .25425 & 1.0631 & {$[.315]$} \\
dLNFP2 & .84996 & .41224 & 2.0618 & {$[.069]$} \\
dLNEP & .36848 & .13539 & 2.7217 & {$[.024]$} \\
dLNEP1 & .010612 & .15116 & .070205 & {$[.946]$} \\
dLNEP2 & -.20499 & .12216 & -1.6780 & {$[.128]$} \\
dLNDP & .55004 & .40819 & 1.3475 & {$[.211]$} \\
dLNHFC & $.9757 \mathrm{E}-3$ & .021764 & .044830 & {$[.965]$} \\
dLNHFC1 & .0071841 & .031046 & .23140 & {$[.822]$} \\
dLNHFC2 & -.024972 & .018422 & -1.3556 & {$[.208]$} \\
dC & -9.9955 & 3.1513 & -3.1719 & {$[.011]$} \\
ecm(-1) & -.95000 & .29007 & -3.2750 & {$[.010]$} \\
\hline ".Dependent variable is dLNFR ----20 observations used for estimation from 1994 to 2013 \\
Source: author's calculation using MICROFIT software
\end{tabular}

Error correction model provide the snap short of the relationships between short-run coefficients and long-run coefficients. The Table 4 present the results of ECM model which shows that energy prices has significant as P-value is less than $5 \%$. Similarly coefficient of error correction model is estimated at -0.95 and perfectly significant because P-value $(0.10)$ 
less than 5\% also having right sign (-) which mean ECM model rapidly converge to long-run equilibrium. Results shows $95 \%$ previous year shock converge in current year toward the long-run equilibrium.

Table 5

Diagnostics Tests of Selected ARDL Model

\begin{tabular}{cc}
\hline LM Test Statistics & \\
\hline Serial Correlation & Normality \\
CHSQ. $(1)=3.5319[.060]$ & CHSQ. $(2)=1.3820[.501]$ \\
Functional Form & Heteroskedasticity \\
CHSQ. $(1)=4.5285[.033]$ & CHSQ. $(1)=.70717[.400]$ \\
\hline
\end{tabular}

The above table of Diagnostic test shows that the ARDL model has significantly overcome the assumptions of Serial correlation, Normality, functional form and heteroskedasticity.

\subsection{Qualitative Findings}

Nvivo10 has different techniques for data analysis especially in qualitative research i.e. transliterating the recorded video and audio interviews, coding of documented data. In this study thematic analysis from past relevant studies are conducted through Word tree map analysis. Tree map is used to determine the least or most critical consequences of the selected study; consequences are derived from different themes of different sizes based on their frequent repetition in the analysis. Ozkan (2004) said that NVivo provide fine support in data organizing and analysis but still its scholars hard work in data management, coding and interpretation.

Figure 4

Major Consequences of Rising food prices-Word Tree Map

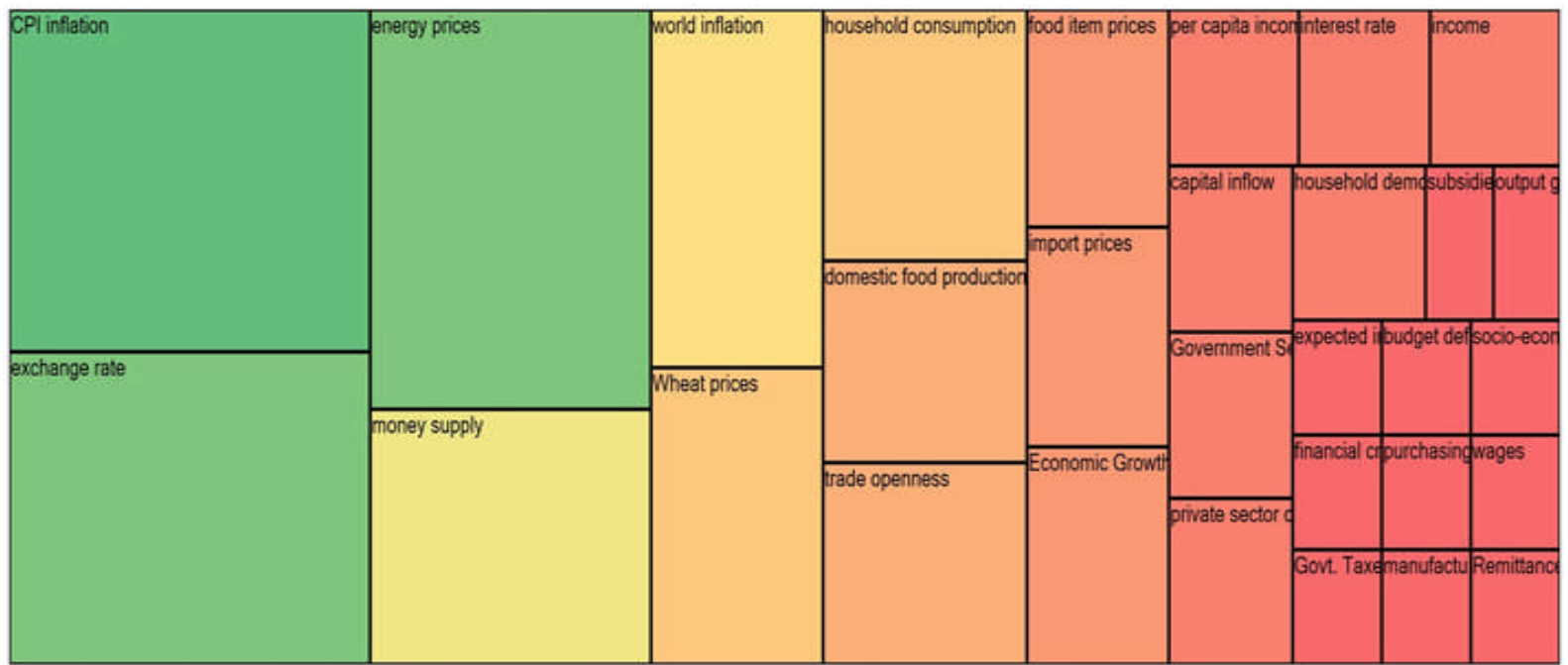

Word Tree Map has been used to demonstrate the extent of the different consequences of rising food prices. . In Figure 4 Tree map shows the most critical to least critical consequences of rising food commodities prices. CPI inflation, Exchange rate, 
energy prices, money supply are the most critical consequences of rising food items prices because the most numbers of responses from past studies determines the relations of these factors with food prices shock as compared to other consequences of upward going food item prices. Similarly, World inflation, wheat prices, household final consumption, domestic production of food items and trade openness are the critical consequences of rising food items prices because the numbers of responses from past studies determines the associations of these factors with food prices shock as compared to other consequences, whereas the import prices, Economic growth, capital inflow, percapita income, interest rate, household demographic, Government \& private sector credit are less critical consequences of rising food items prices because the few numbers of responses from past studies determines the relations of these factors with food prices variation as compared to other consequences. Expected inflation, budget deficit, socio-economic, financial crisis, Govt. Taxes, manufacturing cost and remittance are the least critical consequences of rising food items prices because the least numbers of responses from previous studies determines the relations of these factors with food prices shock as compared to other consequences.

\section{CONCLUSION AND POLICY IMPLICATION}

The current study has used mixed method approach to determine the impact of global macroeconomic variables like energy prices, Dollar prices/exchange rate and household final consumption on rising food prices in Pakistan during the period of 1991 to 2013. Econometric technique of Autoregressive Distributed Lag (ARDL) to Co-integration along with qualitative data analysis technique like Word cloud map, word tree map and tree mapextent of relationship through NVivo 10 are applied. From the test of Co-integration the study concluded that energy prices (EP), Dollar prices (DP) and Household final consumption (HFC) have long-run relationship with rising food commodities prices, whereas the energy prices and dollar prices have significant positive long-run relationship with rising food commodities prices and household final consumption has insignificant negative relationship. Moreover, ECM model's result shows the negative sign with error correction coefficient which confirm its speed of convergence toward long-run equilibrium relations.

Based on the results, the present study recommends the Government should take serious steps in developing effective monetary and fiscal policy for the long-terms by keeping the concerned of society's wellbeing and development. Government should show deep interest in strengthening and transforming the flowing policies and major economics agendas especially in energy infrastructure to creating the excess energy supply at reduced prices in the country so that prices of food commodities will be controlled. Government can done this through proper planning, wipeout the corruption element from the direct responsible institution, by developing the pure and clean process of energy commodities procurement from foreign markets on timely basis, government should increase the capacity of current energy sources and also develop and explore new alternative efficient and effective sources of energy supply by dedicating the appropriate percentage of national budget for research \& development, human resource training and acquisition of energy sector technology to ensure the continued supply of energy supply at very low prices. Exchange rate/ dollar prices also effect rising food prices directly in positive direction which should be controlled through tight monetary policies and keeping the dollar value stable in the country. Government can done this by attracting more new foreign investors, by developing corporate supporting and promoting policies especially in export sector. 
Based on the qualitative results it is concluded that the global economic variables play major role along with others variables in raising the food prices; different variables have different magnitude of relationship with rising food prices in different situation so all of them are important to consider because it seriously affect the life of poor \& middle class families all over the world especially in developing country like Pakistan. There are many causes of high food prices in Pakistan like poor planning about rapidly increase in consumption, lack of accountability, and poor distribution system in both rural and urban areas of Pakistan.

The policy effect of the current study's results suggested that low energy prices and stable dollar prices conservation policies cannot be applied without determined the long-run country's economic growth. Therefore it is compulsory for the Government to develop and integrated efficient and effective energy and monetary policy with long-term future development outline of controlling food inflation.

\section{REFERENCES}

Adnan Haider et al (2013) Determinants of Energy Inflation in Pakistan: An Empirical Analysis "Institute of Business Administration, Karachi, Pakistan".

Alem.Y and Soderbom.M (2010) Household-Level Consumption in Urban Ethiopia: The Impact of Food Price Inflation and Idiosyncratic Shocks "Centre for the Study of African Economies Series" (Ref: CSAE WPS/2010-24 )

Asjed.R et al (2013) an empirical investigation of domestic and external determinants of inflation in Pakistan "Pakistan Economic and Social Review" Volume 51, No. 1 (Summer 2013), pp. 55-7

Batten A Jonathan et al. (2013) On the economic determinants of the gold-inflation relation "Resources Policy" Volume 41 (2014) 101-108 www.elsevier.com/locate/resourpol

Dick Durevall and Bo Sjö (2012) the Dynamics of Inflation in Ethiopia and Kenya "African Development Bank Group" Working Paper No. 151

Dubihlela. D and Sekhampu J Tshediso (2012) The Impact of Rising Food Prices on the Households in a Low Income Township in South Africa "Mediterranean Journal of Social Sciences" Vol. 3 (3) September 2012 ISSN 2039-2117

Friedman, Milton (1963), Inflation: Causes and Consequences. The Council for Economic Education Bombay, India.

Federal Reserve (http: //www.federalreserve.gov/)

Hussain, Manzoor (2005). 'Inflation and Growth: Estimation of Threshold Point for Pakistan', Pakistan Business Review, October 2005.

International Monetary Fund (2011), Annual Report of the Executive Board for the financial year end at 30 June 2011.

Jalil Abdul et al. (2013) Fiscal deficit and inflation: New evidences from Pakistan using a bounds testing approach "Economic Modeling" Volume 37 (2014) 120-126 www.elsevier.com/locate/ecmod

J. Davidson et al (2011) Explaining UK Food Price Inflation "Transparency of Food Pricing (TRANSFOP)" Working Paper \# 1 Seventh Framework Programme Grant Agreement No. KBBE-265601-4-TRANSFOP

Joyia A Salman \& Shahzad Adnan (2013) Determinants of High Food Prices; the Case of Pakistan "Pakistan Economic and Social Review" Volume 51, No. 1 (Summer 2013), pp. 93-107 
Kemal A Ali et al (2012) The Determinants of Food Prices in Pakistan "The Lahore Journal of Economics" 17: 1 (Summer 2012): pp. 101-128

Khan, A. H. and M. A. Qasim (1996), Inflation in Pakistan revisited. "The Pakistan Development Review", Volume 35(4), Part II, pp. 747-759. http://www.jstor.org/stable/41259996

Khan, Mohsin (2005). 'Inflation and Growth in MCD Countries,' Mimeo, International Monetary

Khan A Aleem et al (2007) Determinants of Recent Inflation in Pakistan "Karachi, Pakistan: Social Policy and Development Center" MPRA Paper No. 16254, posted 15. July 2009 http://mpra.ub.uni-muenchen.de/16254/

Khan U Safdar and Saqib F Omar (2010) Political instability and inflation in Pakistan" Journalof Asian Economics" Volume 22 (2011) 540-549

Khalid B Muhammad et al (2013) effect of international gold price, oil price and foreignexchange rate on inflation in Pakistan, "International journal of management research and business strategy" ISSN 2319-345X www.ijmrbs.com Vol. 2, No. 2, April 2013

Le V Trung and Nguyen T T Vinh (2011) the impact of oil prices, real effective exchange rate and inflation on economic activity: Novel evidence for Vietnam "Discussion Paper Series" Research Institute for Economics \& Business Administration, Kobe University

Lodhi N Rab et al (2013) Empirical Investigation of the Factors Affecting Foreign Direct Investment in Pakistan: ARDL Approach "World Applied Sciences Journal" 22 (9): 1318-1325, 2013.

Mohd S Shaari et al., (2012). The Effects of Oil Price Shocks and Exchange Rate Volatility on Inflation: Evidence from Malaysia. "International Business Research"; Vol. 5, No. 9; 2012 ISSN 1913-9004

Muhammad N Hanif. (2012). A Note on Food Inflation in Pakistan, "Pakistan Economic and Social Review" Volume 50, No. 2 (Winter 2012), pp. 183-206.

Mushtaq, K., A. Ghafoor, Abedullah and F. Ahmad (2011), Impact of monetary and macroeconomic factors on wheat prices in Pakistan: Implications for food security. The Lahore Journal of Economics, Volume 16(1), pp. 95-110.

Peter E Arinze (2011) the impact of oil price on the Nigerian economy "JORIND" (9)1 June, 2011. ISSN 1596-8303. www.transcampus.org/journals. www.ajol.info/journals/jorind

R. Salim and S. Rafiq (2011),'The impact of Crude oil price volatility on selected Asian emerging economies"

Reyes, C. (2010). Below poverty measures. Beijing: World Bank.

Saira Tufail \& Sadia Batool (2013) An Analysis of the Relationship between Inflation and Gold Prices: Evidence from Pakistan "The Lahore Journal of Economics" $18: 2$ (Winter 2013): pp. 1-35

Tan B Hui and Cheng y Ming (2002) Inflation in Malaysia "International journal of Social Economics" Vol. 29 No. 5, 2002, pp. 411-425.

Trung, V. T., \& Vinh, N. T. T. (2011). The Impact of Oil Prices, Real Effective Exchange Rateand Inflation on Economic activity: Novel Evidence For Vietnam. Discussion Paper Series. RIEB Kobe University

UN Inter-agency assessment mission on impact of food crisis in Pakistan (2008)www.who.int/hac/crises/pak/pakistan_food_crisis_un_assessment.pdf 